\title{
Titrimetric and Spectrophotometric Assay of Ganciclovir in Pharmaceuticals Using Cerium(IV) Sulphate as the Oxidimetric Agent
}

\author{
Pavagada J. Ramesh, Kanakapura Basavaiah, Cijo M. Xavier, \\ Kudige N. Prashanth, Madihalli S. Raghu, and Kanakapura B. Vinay \\ Department of Chemistry, University of Mysore, Manasagangothri, Mysore 570 006, India \\ Correspondence should be addressed to Kanakapura Basavaiah, basavaiahk@yahoo.co.in
}

Received 1 January 2012; Accepted 23 February 2012

Academic Editors: T. Bolanca, A. Carrasco-Pancorbo, A. Orte, and B. Rittich

Copyright ( $) 2012$ Pavagada J. Ramesh et al. This is an open access article distributed under the Creative Commons Attribution License, which permits unrestricted use, distribution, and reproduction in any medium, provided the original work is properly cited.

\begin{abstract}
Titrimetric and spectrophotometric assay of ganciclovir (GNC) is described using cerium(IV) sulphate as the oxidimetric reagent. The methods are based on the oxidation of GNC with a measured excess of cerium(IV) sulphate in acid medium followed by determination of the unreacted oxidant by two different reaction schemes. In titrimetry, the unreacted oxidant was determined by back titration with ferrous ammonium sulphate (FAS) in sulphuric acid medium, and spectrophotometry involves the reaction of residual cerium(IV) with p-DMAB to form brownish-coloured p-dimethylamino quinoneimine whose absorbance was measured at $460 \mathrm{~nm}$. In both methods, the amount of cerium(IV) sulphate reacted corresponds to GNC concentration. Titrimetry is applicable over $3-10 \mathrm{mg}$ range where as, in spcetrophotometry, the calibration graph is linear over the range of $2-10 \mu \mathrm{g} \mathrm{mL}$ and the calculated molar absorptivity value is $1.960 \times 10^{4} \mathrm{~L} \mathrm{~mol}^{-1} \mathrm{~cm}^{-1}$. The validity of the proposed methods was tested by analyzing pure and dosage forms containing GNC. Statistical treatment of the results reflects that the proposed procedures are precise, accurate, and easily applicable for the determination of GNC pure form and in pharmaceutical formulations.
\end{abstract}

\section{Introduction}

Ganciclovir (GNC) chemically known as 2-amino-9-\{[(1,3dihydroxypropan-2-1)oxy]methyl $\}$-6,9-dihydro-3H-purin6 -one (Figure 1) is a nucleoside analogue widely used in the treatment of cytomegalovirus infections.

It has been proved effective against cytomegalovirus in immunocompromised patients, mainly in those with the acquired immunodeficiency syndrome (AIDS), congenital immunodeficiency, or in individuals following organ transplantation $[1,2]$. Various techniques have been developed for the determination of GNC in pharmaceuticals. It is official in the United States Pharmacopoeia [3].

The most extensively used technique for the quantitation of ganciclovir is HPLC, but most of the procedures using this technique are devoted to body fluids like plasma [818], tissues [19], serum [20], and blood samples [21]. HPLC has also been applied for the determination of GNC in eye drops [22]. GNC in bulk drug and in its formulations has been assayed by UV-spectrometry by measuring the absorbance of drug in $0.1 \mathrm{M} \mathrm{HCl}$ and $0.1 \mathrm{M} \mathrm{NaOH}$ at 253 and $266 \mathrm{~nm}$, respectively. The methods are reported to be moderately sensitive with molar absorptivity values of $\sim 2.0 \times 10^{3}$. There are only three reports on the use of visible spectrophotometry for the assay of GNC in pharmaceuticals. Schelling et al. [4] have devised an enzyme kinetic method which involves the use of multiple reagents and scrupulously controlled experimental variables. The procedure also requires expensive radiolabelled substrates. Recently, Gouda [5] has reported the application of five $\sigma$ and $\pi$-acceptors for the spectrophotometric determination of GNC in its formulations via charge-transfer complexation reaction. The methods have been found applicable over 5$225 \mu \mathrm{g} \mathrm{mL}^{-1}$ ranges with limits detection (LOD) values in the range of $0.36-2.45 \mu \mathrm{g} \mathrm{mL}^{-1}$. In a very recent report, [6] Sarsambi et al. have described two procedures based on Schiff 
TABLE 1: Comparison of the performance characteristics of the proposed methods with the published methods.

\begin{tabular}{|c|c|c|c|c|c|c|}
\hline $\begin{array}{l}\text { Sl. } \\
\text { No. Reagent/s used }\end{array}$ & Methodology & $\begin{array}{l}\lambda_{\max } \\
(\mathrm{nm})\end{array}$ & Linear range & $\operatorname{LOQ}\left(\mu \mathrm{g} \mathrm{mL}^{-1}\right)$ & Remarks & Ref. \\
\hline (1) ATP, NADH, NAD & Enzymatic & 340 & - & - & $\begin{array}{l}\text { Requires vigorous control of } \\
\text { experimental variables and } \\
\text { expensive radiolabelled } \\
\text { substrates, multiple reagents } \\
\text { required. }\end{array}$ & {$[4]$} \\
\hline (2) $\sigma$-and $\pi$-donors & $\begin{array}{l}\mathrm{C}-\mathrm{T} \text { complexation } \\
\text { reaction }\end{array}$ & - & $5-225 \mu \mathrm{g} \mathrm{mL}^{-1}$ & $0.36-2.45 \mu \mathrm{g} \mathrm{mL}^{-1}$ & $\begin{array}{l}\text { Less sensitive and multiple } \\
\text { reagents used. }\end{array}$ & {$[5]$} \\
\hline $\begin{array}{l}\text { (a) } \\
\text { p-dimethylamino- } \\
\text { (3) cinnamaldehyde } \\
\text { and MBTH }\end{array}$ & $\begin{array}{l}\text { Schiff base } \\
\text { formation }\end{array}$ & - & $10-50 \mu \mathrm{g} \mathrm{mL}^{-1}$ & - & $\begin{array}{l}\text { Poorly sensitive and expensive } \\
\text { reagents used. }\end{array}$ & [6] \\
\hline $\begin{array}{l}\text { (b) Iron(III)- } \\
\text { MBTH }\end{array}$ & $\begin{array}{l}\text { Oxidative coupling } \\
\text { reaction }\end{array}$ & & $50-250 \mu \mathrm{g} \mathrm{mL}^{-1}$ & & & \\
\hline $\begin{array}{l}\text { (4) } \mathrm{Ce}(\mathrm{IV}) \text {-rhodamine } \\
\text { in } \mathrm{H}_{2} \mathrm{SO}_{4} \text { medium }\end{array}$ & $\begin{array}{l}\text { Chemiluminescence } \\
\text { reaction }\end{array}$ & - & $5 \times 10^{-8} \mathrm{~g} \mathrm{~mL}^{-1}$ & $2.35 \times 10^{-8} \mathrm{~g} \mathrm{~mL}^{-1}$ & $\begin{array}{l}\text { Requires complicated and } \\
\text { expensive flow-injection } \\
\text { assembly. }\end{array}$ & {$[7]$} \\
\hline $\begin{array}{l}\text { (5) } \mathrm{Ce}(\mathrm{IV})-\mathrm{PDMAB}_{\mathrm{IN}} 4 \mathrm{M} \mathrm{HClO}_{4}\end{array}$ & $\begin{array}{l}\text { Oxidative coupling } \\
\text { reaction }\end{array}$ & 460 & $2-10 \mu \mathrm{g} \mathrm{mL}^{-1}$ & $0.15 \mu \mathrm{g} \mathrm{mL}^{-1}$ & $\begin{array}{l}\text { Sensitive, inexpensive } \\
\text { instrumental setup, use of } \\
\text { ecofriendly chemicals, use of } \\
\text { aqueous system. }\end{array}$ & $\begin{array}{l}\text { This } \\
\text { work }\end{array}$ \\
\hline
\end{tabular}

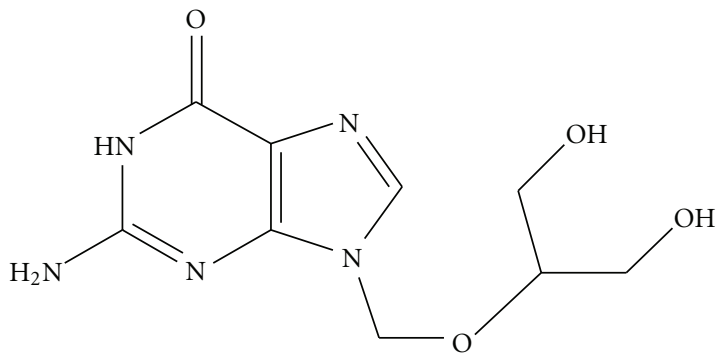

FIGURE 1: Structure of Ganciclovir.

base formation using $\mathrm{p}$-dimethylamino cinnamaldehyde and oxidative coupling reaction involving the use of iron(III) and MBTH, but the methods are poorly sensitive and require heating at $40^{\circ} \mathrm{C}$, with linear dynamic range of 10 $50 \mu \mathrm{g} \mathrm{mL}^{-1}$ and $50-250 \mu \mathrm{g} \mathrm{mL}^{-1}$, respectively. The methods also employ expensive reagents. A flow injection chemiluminescence method has also been described by Wang et al. [7]. Though the method appears to be sensitive with an LOD of $2.35 \mu \mathrm{g} \mathrm{mL}^{-1}$, it requires a complicated and expensive flowinjection assembly as shown in Table 1.

No titrimetric method has ever been reported for GNC despite its simplicity and versatility. In this paper, titrimetric and spectrophotometric determination of GNC is described. The methods are based on the oxidation of drug with a measured excess of Ce(IV) sulphate followed by the determination of residual oxidant either by titration with iron(II) in titrimetry or by spectophotometry involving the use of $\mathrm{Ce}(\mathrm{IV})$ and $\mathrm{p}-\mathrm{DMAB}$. The developed methods were optimized and validated as per the guidelines of the International Conference on Harmonization [23]. The methods are important alternatives to other analytical methods with clear advantages in terms of simplicity, cost effectiveness, speed, and sensitivity.

\section{Materials and Methods}

2.1. Instrument. Absorbance measurements were made on a Systronics model 106 digital spectrophotometer (Ahmedabad, India) provided with $1 \mathrm{~cm}$ matched quartz cells.

2.2. Material and Reagents. All chemicals and reagents used were of analytical or pharmaceutical grade and distilled water was used to prepare the solutions.

Sulphuric Acid (0.1 M; 0.5 M; $2 \mathrm{M} ; 5 \mathrm{M}$ ). It was prepared by appropriate dilution of the conc. $\mathrm{H}_{2} \mathrm{SO}_{4}$ (SD Fine Chem, Mumbai, India, sp. gr. 1.84) with water.

Perchloric Acid $\left(\mathrm{HClO}_{4} ; 4 \mathrm{M}\right)$. It was prepared by diluting concentrated acid (Merck, Mumbai, India, assay 70\%) appropriately with water to get $4 \mathrm{M}$ for spectrophotometric method.

Cerium (IV) Sulphate Solution (0.02 M and $\left.300 \mu \mathrm{gmL}^{-1}\right)$. A stock standard solution equivalent to $0.02 \mathrm{M}$ cerium(IV) sulphate was prepared by dissolving $4.04 \mathrm{~g}$ of the chemical (Loba Chemie, Mumbai, India, assay 99.9\%) in $14 \mathrm{~mL}$ of conc. $\mathrm{H}_{2} \mathrm{SO}_{4}$ and diluting to $500 \mathrm{~mL}$ with water in a $500 \mathrm{~mL}$ standard flask, mixed well, filtered using glass wool, standardized [24] and used in titrimetric work. The stock solution was then diluted appropriately with $4 \mathrm{M}$ $\mathrm{HClO}_{4}$ to obtain a working concentration of $300 \mu \mathrm{g} \mathrm{mL}^{-1}$ in cerium(IV) sulphate for spectrophotometric method. 


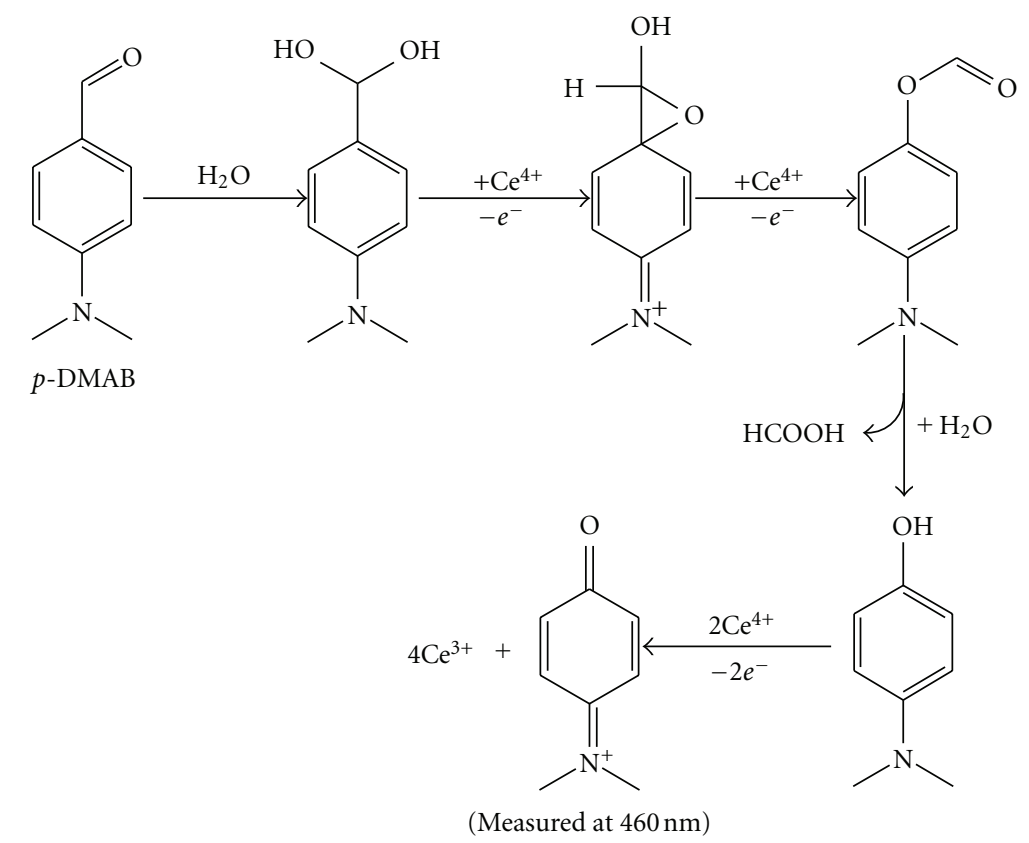

SCHEme 1: The possible reaction mechanism for the oxidation of p-DMAB by Ce(IV) in the presence of $\mathrm{HClO}_{4}$ medium.

Ferrous Ammonium Sulphate Solution (0.02M). A stock solution of FAS $(0.02 \mathrm{M})$ was prepared by dissolving $3.92 \mathrm{~g}$ of the chemical (Loba Chemie, Mumbai, India, assay 99$101 \%$ ) in water containing $5 \mathrm{~mL}$ of $0.5 \mathrm{M} \mathrm{H}_{2} \mathrm{SO}_{4}$ and diluted to volume in a $500 \mathrm{~mL}$ calibrated flask with water and used in titrimetric assay.

Ferroin Indicator Solution. It was prepared by dissolving $1.485 \mathrm{~g}$ of 1,10-phenanthroline monohydrate and $0.695 \mathrm{~g}$ of $\mathrm{FeSO}_{4} \cdot 7 \mathrm{H}_{2} \mathrm{O}$ in water and diluted to $100 \mathrm{~mL}$ [25].

Dimethylaminobenzaldehyde ( $p$-DMAB; 0.5\%). An accurately weighed $1.25 \mathrm{~g}$ of p-DMAB (Merck, Mumbai, India) was transferred to a $250 \mathrm{~mL}$ volumetric flask, dissolved in $4 \mathrm{M} \mathrm{HClO}_{4}$ and the volume was made up to the mark with the same solvent.

Standard GNC Solution (1 $\mathrm{mg} \mathrm{mL}^{-1}$ and $\left.20 \mu \mathrm{gmL} \mathrm{L}^{-1}\right)$. A stock standard solution containing $1 \mathrm{mg} \mathrm{mL}^{-1} \mathrm{GNC}$ was prepared by dissolving $100 \mathrm{mg}$ of pure GNC in $0.1 \mathrm{M} \mathrm{H}_{2} \mathrm{SO}_{4}$ the volume was brought to $100 \mathrm{~mL}$ with water in a volumetric flask and used for titrimetric assay.

A $100 \mu \mathrm{g} \mathrm{mL}^{-1}$ GNC standard solution was also prepared by dissolving an accurately weighed $10 \mathrm{mg}$ of GNC in $4 \mathrm{M}$ $\mathrm{HClO}_{4}$ and diluting to the mark with the same solvent in a $100 \mathrm{~mL}$ calibrated flask, and this was diluted with the same solvent to get a working concentration of $20 \mu \mathrm{g} \mathrm{mL}^{-1} \mathrm{GNC}$ and used spectrophotometric method.

Two brands of tablets containing GNC, Ganguard500 (Ranbaxy, Superspeciality Ltd., Ahamadabad, India) and Nataclovir-250 (Natco Pharma Ltd., Hyderabad, and India) used in the investigation were purchased from local commercial sources.

\subsection{Methods}

Titrimetry. A $10 \mathrm{~mL}$ aliquot of standard drug solution in $0.1 \mathrm{M} \mathrm{H}_{2} \mathrm{SO}_{4}$ containing $1-10 \mathrm{mg}$ of GNC was measured accurately and taken in a $100 \mathrm{~mL}$ titration flask; $5 \mathrm{~mL}$ of $0.1 \mathrm{M} \mathrm{H}_{2} \mathrm{SO}_{4}$ and $2 \mathrm{~mL}$ of $2 \mathrm{M} \mathrm{H}_{2} \mathrm{SO}_{4}$ were added to the flask. By means of a pipette, $10 \mathrm{~mL}$ of $0.02 \mathrm{M} \mathrm{Ce}(\mathrm{IV}) \mathrm{SO}_{4}$ was added, content-mixed and the flask kept aside for $15 \mathrm{~min}$. Then, the unreacted cerium(IV) solution was titrated against $0.02 \mathrm{M}$ FAS using ferroin indicator to a first appearance of orange red color. A blank titration was performed with $10 \mathrm{~mL} 0.1 \mathrm{M} \mathrm{H}_{2} \mathrm{SO}_{4}$ in place of GNC solution.

The amount of GNC in the aliquot was computed from the formula:

$$
\text { Amount }(\mathrm{mg})=\frac{V M_{w} S}{n}
$$

where $V$ is $\mathrm{mL}$ of cerium(IV) sulphate reacted, $M_{w}$ is relative molecular mass of drug, $S$ is strength of cerium(IV) sulphate, moles $\mathrm{L}^{-1}$, and $n$ is number of moles of cerium(IV) sulphate reacting with per mole of GNC.

Spectrophotometry. Varying aliquots $(0.0,1.0,2.0,3.0,4.0$, and $5.0 \mathrm{~mL}$ ) of $20 \mu \mathrm{g} \mathrm{mL}^{-1}$ GNC solution were transferred into a series of $10 \mathrm{~mL}$ calibrated flasks by means of a microburette and the total volume was adjusted to $5 \mathrm{~mL}$ by adding requisite volume of $4 \mathrm{M} \mathrm{HClO}_{4}$. To each flask $1 \mathrm{~mL}$ of $300 \mu \mathrm{g} \mathrm{mL}^{-1}$ Cerium(IV) sulphate was added from a microburette. The content was mixed well and the flasks were let stand for $10 \mathrm{~min}$ with occasional shaking. Then, was added $1 \mathrm{~mL}$ of $0.5 \% \mathrm{p}$-DMAB to each flask, again the flasks were let stand for $5 \mathrm{~min}$. The volume was diluted to the mark with $4 \mathrm{M} \mathrm{HClO}_{4}$, mixed well and the absorbance of each solution was measured at $460 \mathrm{~nm}$ against water. 
TABLE 2: Sensitivity and regression parameters.

\begin{tabular}{lc}
\hline Parameter & Value \\
\hline$\lambda_{\max }, \mathrm{nm}$ & 460 \\
Linear range, $\mu \mathrm{g} \mathrm{m}^{-1}$ & $2.0-10.0$ \\
Molar absorptivity $(\varepsilon), \mathrm{L} \mathrm{mol}^{-1} \mathrm{~cm}^{-1}$ & $1.960 \times 10^{4}$ \\
Sandell sensitivity*,$\mu \mathrm{g} \mathrm{cm}^{-1}$ & 0.0132 \\
Limit of detection (LOD), $\mu \mathrm{g} \mathrm{m}^{-1}$ & 0.05 \\
Limit of quantification (LOQ), $\mu \mathrm{g} \mathrm{m}^{-1}$ & 0.15 \\
Regression equation, $Y^{* *}$ & \\
Intercept ( $a$ ) & 0.7240 \\
Slope $(b)$ & -0.0650 \\
Standard deviation of $a\left(S_{a}\right)$ & 0.4448 \\
Standard deviation of $b\left(S_{b}\right)$ & 0.0703 \\
Regression coefficient $(r)$ & -0.9995 \\
\hline
\end{tabular}

${ }^{*}$ Limit of determination as the weight in $\mu$ g per $\mathrm{mL}$ of solution, which corresponds to an absorbance of $A=0.001$ measured in a cuvette of cross-sectional area $1 \mathrm{~cm}^{2}$ and $l=1 \mathrm{~cm} .{ }^{* *} Y=a+b X$, where $Y$ is the absorbance, $X$ is concentration in $\mu \mathrm{g} / \mathrm{mL}, a$ is intercept, and $b$ is slope.

A calibration graph was prepared by plotting the measured absorbance versus concentration of GNC, and the concentration of the unknown was red from the calibration graph or deduced from the regression equation derived using the Beer's law data.

Procedure for Tablets. Twenty tablets were weighed accurately and finely powdered. A quantity of the powdered tablet containing $100 \mathrm{mg}$ of GNC was weighed accurately and transferred into a $100 \mathrm{~mL}$ calibrated flask, $60 \mathrm{~mL}$ of $0.1 \mathrm{M}$ $\mathrm{H}_{2} \mathrm{SO}_{4}$ was added, and the content was shaken thoroughly for 15-20 min to extract the drug into the liquid phase; the volume was finally diluted to the mark with $0.1 \mathrm{M} \mathrm{H}_{2} \mathrm{SO}_{4}$, mixed well and filtered using a Whatman no. 42 filter paper. First $10 \mathrm{~mL}$ portion of the filtrate was discarded, and a convenient aliquot of the subsequent portion of filtrate was subjected to analysis by titrimetry.

The tablet extract containing GNC at a concentration of $1 \mathrm{mg} \mathrm{mL}-1$ was then diluted stepwise with $4 \mathrm{M} \mathrm{HClO}_{4}$ to obtain a working concentration of $20 \mu \mathrm{g} \mathrm{mL}^{-1}$ in GNC and a convenient aliquot was then subjected to analysis by spectrophotometer procedure described earlier.

Placebo Blank Analysis. A placebo blank of the composition: talc $(20 \mathrm{mg})$, starch $(10 \mathrm{mg})$, acacia $(15 \mathrm{mg})$, methyl cellulose $(10 \mathrm{mg})$, sodium citrate $(10 \mathrm{mg})$, magnesium stearate $(15 \mathrm{mg})$, and sodium alginate $(10 \mathrm{mg})$ was made and its solution was prepared as described under "procedure for tablets," and then subjected to analysis.

Procedure for the Determination of GNC in Synthetic Mixtures. To the placebo blank of the composition described above, $100 \mathrm{mg}$ of pure GNC was added and homogenized, transferred to a $100 \mathrm{~mL}$ standard flask, and solution-prepared as described under "procedure for tablets." The resulting solution was assayed ( $n=5)$ by titrimetry according to the same procedure described above.

The synthetic mixture solution $\left(1 \mathrm{mg} \mathrm{mL}^{-1}\right.$ in GNC) was then diluted stepwise with $4 \mathrm{M} \mathrm{HClO}_{4}$ to obtain a working concentration of $20 \mu \mathrm{g} \mathrm{mL}^{-1}$ in GNC for spectrophotometric method. A convenient aliquot was then subjected to analysis by spectrophotometric procedure described above. The analysis was done to study the interferences from excipients such as talc, starch, acacia, anhydrous lactose, sodium alginate, magnesium stearate, and methyl cellulose.

\section{Results and Discussions}

The proposed methods are indirect and are based on the determination of unreacted cerium(IV), after the reaction between GNC and the oxidant is ensured to be complete, and rely on two different well-known reactions which are shown below

$$
\begin{aligned}
& \mathrm{GNC}+\mathrm{Ce}(\mathrm{IV}) \text { (known acess) } \\
& \stackrel{\mathrm{H}^{+}}{\longrightarrow} \text { Oxidation product of GNC + Unreacted } \mathrm{Ce}(\mathrm{IV}) \\
& \text { Unreacted } \\
& \longrightarrow \text { Titrated with standard FAS using ferroin indicator } \\
& \quad(\text { Titrimetry }) \\
& \text { Unreacted }+ \text { p-DMAB in } \mathrm{HClO}_{4} \\
& \longrightarrow \text { Orange coloured product measured medium } \\
& \text { at } 460 \mathrm{~nm} \text { (Spectrophotometry). }
\end{aligned}
$$

The titrimetric method involves oxidation of GNC by a known excess of cerium(IV) sulphate in $\mathrm{H}_{2} \mathrm{SO}_{4}$ medium and the unreacted oxidant was determined by back titration with FAS. The reaction between GNC and cerium(IV) was found to occur in 1:1 (drug:oxidant) stoichiometric ratio and all the calculations are based on this stoichiometric ratio. Using $0.02 \mathrm{M}$ cerium(IV), 3-10 mg of GNC was conveniently determined.

Redox reactions always preferred highly acidic conditions. The oxidation reactions of some compounds are very rapid when perchloric acid $\left(\mathrm{HClO}_{4}\right)$ medium is maintained [26-29]. This is attributed to the highest oxidation potential of cerium(IV) in $\mathrm{HClO}_{4}\left(E_{o}=1.75 \mathrm{~V}\right)$ as compared to that of cerium(IV) in $\mathrm{H}_{2} \mathrm{SO}_{4}\left(E_{o}=1.44 \mathrm{~V}\right), \mathrm{HNO}_{3}\left(E_{o}=\right.$ $1.61 \mathrm{~V})$ or $\mathrm{HCl}\left(E_{o}=1.28 \mathrm{~V}\right)$ [30]. The greater oxidation potential of cerium(IV) in perchloric acid overcomes both the slowness of the oxidation process and the inexact stoichiometry encountered in other acids. The solutions of cerium(IV) in hydrochloric acid are unstable owing to the oxidation of chloride ions to chlorine gas [31]. The refore, in spectrophotometry, the unreacted $\mathrm{Ce}^{4+}$ was treated with $\mathrm{p}$-DMAB in $\mathrm{HClO}_{4}$ medium to yield formic acid and p-dimethylaminophenol, which upon further oxidation gave the corresponding quinoinemine derivative [32]. The possible reaction scheme involving the formation of coloured chromogen is given in Scheme 1. 
TABLE 3: Evaluation of intraday and interday accuracy and precision.

\begin{tabular}{|c|c|c|c|c|c|c|c|}
\hline \multirow[b]{2}{*}{ Method* } & \multirow{2}{*}{$\begin{array}{l}\text { GNC } \\
\text { taken }\end{array}$} & \multicolumn{3}{|c|}{ Intraday accuracy and precision } & \multicolumn{3}{|c|}{ Interday accuracy and precision } \\
\hline & & $\begin{array}{l}\text { GNC } \\
\text { found }\end{array}$ & $\% \mathrm{RE}$ & $\% \mathrm{RSD}$ & $\begin{array}{l}\text { GNC } \\
\text { found }\end{array}$ & $\% \mathrm{RE}$ & $\% \mathrm{RSD}$ \\
\hline \multirow{3}{*}{ Titrimetry } & 3.0 & 3.03 & 1.00 & 1.27 & 2.96 & 1.26 & 2.34 \\
\hline & 6.0 & 6.04 & 0.67 & 0.81 & 1.08 & 1.08 & 1.47 \\
\hline & 9.0 & 9.02 & 0.22 & 0.66 & 8.94 & 0.66 & 1.62 \\
\hline \multirow{3}{*}{ Spectrophotometry } & 2.0 & 2.04 & 2.00 & 3.10 & 2.05 & 2.5 & 3.26 \\
\hline & 4.0 & 4.04 & 1.00 & 1.13 & 4.08 & 2.0 & 1.56 \\
\hline & 6.0 & 5.83 & 2.83 & 0.50 & 5.90 & 1.67 & 2.13 \\
\hline
\end{tabular}

RE: relative error; RSD: relative standard deviation.

*In titrimetry, GNCs taken/found are in $\mathrm{mg}$ and they are $\mu \mathrm{g} \mathrm{mL} L^{-1}$ in spectrophotometry.

TABLE 4: Method robustness and ruggedness expressed as intermediate precision (\%RSD).

(a) Titrimetry

\begin{tabular}{|c|c|c|c|c|}
\hline \multirow[b]{3}{*}{ GNC taken, $\mu \mathrm{g} \mathrm{m}^{-1}$} & \multirow{2}{*}{\multicolumn{2}{|c|}{$\begin{array}{c}\text { Robustness } \\
\text { Parameter altered }\end{array}$}} & \multicolumn{2}{|c|}{ Ruggedness } \\
\hline & & & \multirow{2}{*}{$\begin{array}{l}\text { Interanalysts, } \\
(\% \text { RSD })(n=4)\end{array}$} & \multirow{2}{*}{$\begin{array}{l}\text { Interburettes, } \\
(\% \mathrm{RSD})(n=4)\end{array}$} \\
\hline & $\begin{array}{c}\text { Volume of } \mathrm{H} 2 \mathrm{SO} 4^{*} \\
(\% \mathrm{RSD})(n=3)\end{array}$ & $\begin{array}{l}\text { Reaction time* } \\
(\% \text { RSD })(n=3)\end{array}$ & & \\
\hline 3.0 & 1.56 & 2.02 & 1.10 & 1.32 \\
\hline 6.0 & 1.32 & 1.42 & 1.59 & 1.53 \\
\hline 9.0 & 1.65 & 1.11 & 2.50 & 1.25 \\
\hline
\end{tabular}

(b) Spectrophotometry

\begin{tabular}{lcccc}
\hline & \multicolumn{2}{c}{ Robustness } \\
Parameter altered & & \multicolumn{2}{c}{ Ruggedness } \\
GNC taken, $\mu \mathrm{g} \mathrm{m}^{-1}$ & $\begin{array}{c}\text { Volume of p-DMAB } \\
(\% \mathrm{RSD})(n=3)\end{array}$ & $\begin{array}{c}\text { Reaction time* } \\
(\% \mathrm{RSD})(n=3)\end{array}$ & $\begin{array}{c}\text { Interanalysts, } \\
(\% \mathrm{RSD})(n=4)\end{array}$ & $\begin{array}{c}\text { Intercuvetts, } \\
(\% \mathrm{RSD})(n=4)\end{array}$ \\
\hline 2.0 & 1.56 & 2.08 & 1.15 & 1.32 \\
4.0 & 1.32 & 1.40 & 1.29 & 1.53 \\
6.0 & 1.65 & 1.12 & 2.10 & 1.25 \\
\hline
\end{tabular}

${ }^{*}$ Volumes of $5 \mathrm{M} \mathrm{H}_{2} \mathrm{SO}_{4}$ varied were $5 \pm 1 \mathrm{~mL}$, and reaction times were $15 \pm 1 \mathrm{~min}$.

*Volumes of p-DMAB varied were $1 \pm 0.1 \mathrm{~mL}$, and reaction times were $15 \pm 1 \mathrm{~min}$.

Optimization of Experimental Variables. The experimental variables which provided accurate and precise results were optimized.

Titrimetry. The reaction was found to be quantitative and stoichiometric in $\mathrm{H}_{2} \mathrm{SO}_{4}$ medium. A constant reaction stoichiometry of $1: 1$ [GNC: cerium(IV)] was obtained when $1.0-5.0 \mathrm{~mL}$ of $2 \mathrm{M} \mathrm{H}_{2} \mathrm{SO}_{4}$ was used in a total volume of $25 \mathrm{~mL}$. Hence $2 \mathrm{~mL}$ of $2 \mathrm{M} \mathrm{H}_{2} \mathrm{SO}_{4}$ was used as optimum for the reaction between GNC and cerium(IV) giving an overall acidity of $0.1 \mathrm{M}$ with respect to $\mathrm{H}_{2} \mathrm{SO}_{4}$, and for the latter's back titration with iron(II). The reaction time was studied by titrating the unreacted cerium(IV) with iron(II) at different time intervals after addition of oxidant to the acidic solution of GNC. It was found that the reaction yielded a constant stoichimetry in the time range 5 to $15 \mathrm{~min}$, and at the standing time less than $5 \mathrm{~min}$ and greater than $15 \mathrm{~min}$, there was no constant and definite reaction stoichiometry. Hence, it is necessary to terminate the reaction at the end of the fifth min by back-titrating the residual cerium(IV) with iron(II).

Spectrophotometry. Perchloric acid (4M) medium was found necessary for rapid and quantitative reaction between GNC and Cerium(IV) and to obtain maximum and constant absorbance values due to cerium(IV)-p-DMAB reaction product at $460 \mathrm{~nm}$. Therefore, all the solutions (GNC, cerium(IV) and p-DMAB) were prepared in $4 \mathrm{M} \mathrm{HClO}_{4}$ throughout the investigation and the same was maintained as reaction medium. To fix the optimum concentration of $\mathrm{Ce}^{4+}$, different concentrations of oxidant were reacted with a fixed concentration of $\mathrm{p}-\mathrm{DMAB}$ in $\mathrm{HClO}_{4}$ medium and the absorbance measured at $460 \mathrm{~nm}$. A constant and maximum absorbance resulted with $30 \mu \mathrm{g} \mathrm{mL} \mathrm{m}^{-1}$ cerium(IV) sulphate and, hence, different concentrations of GNC were reacted with $1 \mathrm{~mL}$ of $300 \mu \mathrm{g} \mathrm{mL}^{-1}$ cerium(IV) sulphate in $\mathrm{HClO}_{4}$ medium before determining the residual $\mathrm{Ce}^{4+}$ via the reaction scheme illustrated earlier. This facilitated 
TABLE 5: Results of analysis of tablets by the proposed methods.

\begin{tabular}{|c|c|c|c|c|}
\hline \multirow{2}{*}{ Tablet brand name } & \multirow{2}{*}{$\begin{array}{l}\text { Label claim, } \\
\text { mg/tablet }\end{array}$} & \multicolumn{3}{|c|}{ Found* (percent of label claim $\pm \mathrm{SD}$ ) } \\
\hline & & Reference method & Titrimetry & Spectrophotometry \\
\hline \multirow{3}{*}{ Ganguard 500} & \multirow{3}{*}{500} & \multirow{3}{*}{$100.5 \pm 0.73 \%$} & $99.2 \pm 0.63$ & $99.9 \pm 0.53$ \\
\hline & & & $t=3.03$ & $t=0.90$ \\
\hline & & & $F=1.33$ & $F=1.89$ \\
\hline \multirow{3}{*}{ Nataclovir 250} & \multirow{3}{*}{250} & \multirow{3}{*}{$102.3 \pm 1.40 \%$} & $100.5 \pm 1.10$ & $100.5 \pm 1.05$ \\
\hline & & & $t=2.26$ & $t=2.30$ \\
\hline & & & $F=1.62$ & $F=1.78$ \\
\hline
\end{tabular}

* Mean value of five determinations.

The value of $t$ (tabulated) at $95 \%$ confidence level and for four degrees of freedom is 2.77 .

The value of $F$ (tabulated) at 95\% confidence level and for four degrees of freedom is 6.39 .

TABLE 6: Accuracy assessment by recovery experiments.

\begin{tabular}{|c|c|c|c|c|c|}
\hline Method & Tablet studied & GNC tablet* & Pure GNC added* & Total found* & $\begin{array}{c}\text { Pure GNC recovered }{ }^{* *}, \\
\text { Percent } \pm \text { SD }\end{array}$ \\
\hline \multirow{6}{*}{ Titrimetry } & \multirow{3}{*}{ Ganguard 500} & 3.99 & 2.0 & 6.07 & $102.2+0.85$ \\
\hline & & 3.99 & 4.0 & 8.19 & $105.0+0.12$ \\
\hline & & 3.99 & 6.0 & 10.08 & $102.5+0.21$ \\
\hline & \multirow{3}{*}{ Nataclovir 250} & 4.10 & 2.0 & 6.10 & $100.1+0.34$ \\
\hline & & 4.10 & 4.0 & 8.14 & $101.2+0.11$ \\
\hline & & 4.10 & 6.0 & 10.25 & $103.9+0.22$ \\
\hline \multirow{6}{*}{ Spectrophotometry } & \multirow{3}{*}{ Ganguard 500} & 4.13 & 2.0 & 6.18 & $101.4+0.12$ \\
\hline & & 4.13 & 4.0 & 8.34 & $105.2+0.90$ \\
\hline & & 4.13 & 6.0 & 10.25 & $103.8+0.56$ \\
\hline & \multirow{3}{*}{ Nataclovir 250} & 3.98 & 2.0 & 6.26 & $107.1+0.12$ \\
\hline & & 3.98 & 4.0 & 8.20 & $105.7+0.80$ \\
\hline & & 3.98 & 6.0 & 10.17 & $104.8+0.76$ \\
\hline
\end{tabular}

${ }^{*} \mathrm{Mg}$ in titrimetry and $\mu \mathrm{g} \mathrm{mL}{ }^{-1}$ in spectrophotometry.

** Mean value of three measuresments.

the optimization of the linear dynamic range over which procedure could be applied for the assay of GNC. The reaction between $\mathrm{GNC}$ and $\mathrm{Ce}^{4+}$ was complete within $15 \mathrm{~min}$ at room temperature $\left(28 \pm 2^{\circ} \mathrm{C}\right)$. After the addition of $\mathrm{p}$ $D M A B$, a standing time of $5 \mathrm{~min}$ was necessary for the formation of coloured product, and thereafter, the coloured product was stable for more than an hour.

3.1. Method Validation. The proposed methods were validated for linearity, sensitivity, precision, accuracy, selectivity, and recovery.

Linearity and Sensitivity. Over the range investigated (3$10 \mathrm{mg}$ GNC), a fixed stoichiometry of 1:1 (GNC: Cerium (IV) sulphate) was obtained in titrimetry which served as the basis for calculations. In spectrophotometry, under optimum conditions a linear relation was found between absorbance and concentration in the ranges given in Table 2 and Beer's law is obeyed in the inverse manner. Sensitivity parameters such as molar absorptivity and Sandel sensitivity, and limits of detection and quantification calculated as per the current ICH guidelines [23] are compiled in Table 2.
Precision and Accuracy. Intraday precision and accuracy of the proposed methods were evaluated by replicate analysis $(n=5)$ of calibration standards at three different concentration levels on the same day. Interday precision and accuracy were determined by assaying the calibration standards at the same concentration levels on five consecutive days. Precision and accuracy were based on the calculated relative standard deviation (RSD, \%) and relative error (RE, \%) of the found concentration compared to the theoretical one, respectively (Table 3).

Selectivity. The proposed methods were tested for selectivity by placebo blank and synthetic mixture analyses. A convenient aliquot of placebo blank solution prepared as described earlier was subjected to analysis by titrimetry and spectrophotometry according to the recommended procedures. In both the cases, there was no interference by the inactive ingredients.

A separate experiment was performed with the synthetic mixture. The analysis of synthetic mixture solution prepared above yielded percent recoveries in the range 102.7-105.4\% with standard deviation of $1.31-3.15$. The results of this study indicated that the inactive ingredients did not interfere 
in the assay. These results further demonstrate the accuracy as well as the precision of the proposed methods.

Robustness and Ruggedness. To evaluate the robustness of the methods, reaction time and $\mathrm{H}_{2} \mathrm{SO}_{4}$ concentrations were slightly altered with reference to optimum values in titrimetry. However, in spectrophotometry, the reaction time and volume of $\mathrm{p}-\mathrm{DMAB}$ were altered. To check the ruggedness, analysis was performed by four different analysts, and on three different burettes (titrimetry) or cuvettes by the same analyst. The robustness and the ruggedness were checked at three different drug levels. The intermediate precision, expressed as RSD (\%), which is a measurement of robustness and ruggedness, was within the acceptable limits (0.72$3.74 \%$ ) as shown in Table 4.

Applicability of the Proposed Methods. The proposed methods were successfully applied to the determination of GNC in pharmaceutical preparations. The results obtained by the proposed methods were compared to those of the reference method [5] by applying Student's $t$-test for accuracy and $F$-test for precision. The results (Table 5) show that the Student's $t$ - and $F$ values at $95 \%$ confidence level are less than the theoretical values, which confirmed that there is no significant difference in the performance of the proposed methods and the reference method with respect to accuracy and precision.

Recovery Studies. The accuracy and validity of the proposed methods were further ascertained by performing recovery studies. Preanalysed tablet powder was spiked with pure GNC at three concentration levels $(50,100$, and $150 \%$ of that in tablet powder) and the total was found by the proposed methods. In all cases, the added GNC recovery percentage values ranged between 101.7 and $109.7 \%$ with standard deviation of 0.54-2.42 (Table 6) indicating that the recovery was good and that the coformulated substance did not interfere in the determination.

\section{Conclusions}

The proposed titrimetric and spectrophotometric methods using $\mathrm{Ce}(\mathrm{IV}) \mathrm{SO}_{4}$ have suitable performance characteristics for application in the determination of ganciclovir. In particular, the titrimetry is much simpler in technique, more rapid than all the methods reported so far for ganciclovir. The proposed spectrophotometric method employs mild working conditions without heating or extraction and as sensitive as many reported methods. The methods are also useful due to high tolerance limit for common excipients found in drug formulations. Hence, these advantages encourage the application of the proposed methods in routine quality control analysis of ganciclovir in pharmaceutical industries.

\section{Acknowledgment}

The authors thank SD Fine Chem. Ltd., India, for gifting pure GNC. Three of the authors P. J. Ramesh, C. M. Xavier, and
K. B. Vinay, thank Jubilant Life Sciences, Nanjangud, Mysore, for kind permission to pursue Ph.D. degree.

\section{References}

[1] H. L. Cantrill, K. Henry, N. H. Melroe, W. H. Knobloch, R. C. Ramsay, and H. H. Balfour, "Treatment of cytomegalovirus retinitis with intravitreal ganciclovir. Long-term results," Ophthalmology, vol. 96, no. 3, pp. 367-374, 1989.

[2] A. Markham and D. Faulds, "Roxithromycin: an update of its antimicrobial activity, pharmacokinetic properties and therapeutic use," Drugs, vol. 48, no. 2, pp. 297-326, 1994.

[3] The United States Pharmacopoeia, XXIV Revision, the National Formulary XIX Rockville, USP Convention, 2000.

[4] P. Schelling, G. Folkers, and L. Scapozza, "A spectrophotometric assay for quantitative determination of kcat of herpes simplex virus type 1 thymidine kinase substrates," Analytical Biochemistry, vol. 295, no. 1, pp. 82-87, 2001.

[5] A. A. Gouda, "Utility of certain $\sigma$ - and $\pi$-acceptors for the spectrophotometric determination of ganciclovir in pharmaceutical formulations," Talanta, vol. 80, no. 1, pp. 151-157, 2009.

[6] P. S. Sarsambi, D. Gowrisankar, A. Sonawane, and A. Faheem, "Visible spectrophotometric determination of ganciclovir by condensation and oxidative coupling reactions," International Journal of Chem Tech Research, vol. 2, no. 1, pp. 282-285, 2010.

[7] N. Wang, Y. Tang, X. Xiong, X. Han, and C. Yu, "A new flowinjection chemiluminescence method for the determination of acyclovir and gancyclovir," Analytical Letters, vol. 39, no. 5, pp. 973-983, 2006.

[8] D. R. Weller, H. H. Balfour, and H. E. Vezina, "Simultaneous determination of acyclovir, ganciclovir, and (R)-9-[4hydroxy-2-(hydroxymethyl)butyl]guanine in human plasma using high-performance liquid chromatography," Biomedical Chromatography, vol. 23, no. 8, pp. 822-827, 2009.

[9] A. Maes, B. Garré, N. Desmet et al., "Determination of acyclovir in horse plasma and body fluids by high-performance liquid chromatography combined with fluorescence detection and heated electrospray ionization tandem mass spectrometry," Biomedical Chromatography, vol. 23, no. 2, pp. 132-140, 2009.

[10] Y. J. Dao, Z. Jiao, and M. K. Zhong, "Simultaneous determination of aciclovir, ganciclovir, and penciclovir in human plasma by high-performance liquid chromatography with fluorescence detection," Journal of Chromatography B, vol. 867, no. 2, pp. 270-276, 2008.

[11] M. Kasiari, E. Gikas, S. Georgakakou, M. Kazanis, and I. Panderi, "Selective and rapid liquid chromatography/negativeion electrospray ionization mass spectrometry method for the quantification of valacyclovir and its metabolite in human plasma," Journal of Chromatography B, vol. 864, no. 1-2, pp. 78-86, 2008.

[12] N. Perrottet, A. Beguin, P. Meylan et al., "Determination of aciclovir and ganciclovir in human plasma by liquid chromatography-spectrofluorimetric detection and stability studies in blood samples," Journal of Chromatography B, vol. 852, no. 1-2, pp. 420-429, 2007.

[13] F. Schenkel, S. Rudaz, Y. Daali, M. K. Oestreicher, J. L. Veuthey, and P. Dayer, "Development and validation of a new reversed-phase ion pairing liquid chromatographic method with fluorescence detection for penciclovir analysis in plasma and aqueous humor," Journal of Chromatography B, vol. 826, no. 1-2, pp. 1-7, 2005. 
[14] D. Teshima, K. Otsubo, T. Yoshida, Y. Itoh, and R. Oishi, "A simple and simultaneous determination of acyclovir and ganciclovir in human plasma by high-performance liquid chromatography," Biomedical Chromatography, vol. 17, no. 8, pp. 500-503, 2003.

[15] S. Kishino, Y. Takekuma, M. Sugawara et al., "Liquid chromatographic method for the determination of ganciclovir and/or acyclovir in human plasma using pulsed amperometric detection," Journal of Chromatography B, vol. 780, no. 2, pp. 289-294, 2002.

[16] N. Shibata, A. Kitamura, Y. Yoshikawa, T. Inoue, T. Bamba, and K. Takada, "Simultaneous determination of aciclovir and ganciclovir in plasma by HPLC and pharmacokinetic interactions," Pharmacy and Pharmacology Communications, vol. 6, no. 11, pp. 501-506, 2000.

[17] R. Boulieu, N. Bleyzac, and S. Ferry, "High-performance liquid chromatographic determination of ganciclovir in plasma," Journal of Chromatography, vol. 567, no. 2, pp. 480-484, 1991.

[18] T. Yoshida, R. Takahashi, K. Imai, H. Uchida, Y. Arai, and T. Oh-Ishi, "A simple, sensitive determination of ganciclovir in infant plasma by high-performance liquid chromatography with fluorescence detection," Journal of Chromatographic Science, vol. 48, no. 3, pp. 208-211, 2010.

[19] S. D. Brown, C. A. White, and M. G. Bartlett, "Hydrophilic interaction liquid chromatography/electrospray mass spectrometry determination of acyclovir in pregnant rat plasma and tissues," Rapid Communications in Mass Spectrometry, vol. 16, no. 19, pp. 1871-1876, 2002.

[20] M. Koel and P. Nebinger, "HPLC determination of serum ganciclovir using ultrafiltration, ultraviolet and fluorescence detection," Journal of Pharmaceutical and Biomedical Analysis, vol. 12, no. 3, pp. 429-432, 1994.

[21] R. Boulieu and N. Bleyzac, "Stability of ganciclovir in blood samples," Journal of Pharmaceutical and Biomedical Analysis, vol. 12, no. 9, pp. 1205-1207, 1994.

[22] G. L. Liang and Henan, "HPLC determination of ganciclovir and ribavirin in eye drops," Yaowu Fenxi Zazhi, vol. 26, no. 9, pp. 1308-1310, 2006.

[23] International Conference On Harmonization of Technical Requirements for Registration of Pharmaceuticals for Human Use, ICH Harmonised Tripartite Guideline, Validation of Analytical Procedures: Text and Methodology Q2(R1), Complementary Guideline on Methodology, London, UK, November 1996, incorporated in November 2005.

[24] J. Basset, R. C. Denney, G. H. Jeffery, and J. Mendham, Vogel's Quantitative Inorganic Analysis, English Language Book Society and Longman, Essex, UK, 4th edition, 1978.

[25] A. I. Vogel, A Text-Book of Quantitative Inorganic Analysis Including Elementary Instrumental Analysis, 1961.

[26] I. A. Darwish, S. A. Hussein, A. M. Mahmoud, and A. I. Hassan, "Spectrophotometric determination of H2-receptor antagonists via their oxidation with cerium(IV)," Spectrochimica Acta-Part A, vol. 69, no. 1, pp. 33-40, 2008.

[27] N. Rajendraprasad, K. Basavaiah, and K. B. Vinay, "Volumetric and spectrophotometric determination of oxcarbazepine in tablets," Acta Chimica Slovenica, vol. 58, no. 3, pp. 621-628, 2011.

[28] K. Basavaiah, V. Ramakrishna, and U. R. A. Kumar, "Use of ceric ammonium sulphate and two dyes, methyl orange and indigo carmine, in the determination of lansoprazole in pharmaceuticals," Acta Pharmaceutica, vol. 57, no. 2, pp. 211-220, 2007.

[29] R. A. Kaselis, W. Leibmann, W. Seaman, J. P. Sickels, E. I. Stearns, and J. T. Woods, "Modified colorimetric assay of pteroylglutamic acid," Analytical Chemistry, vol. 23, no. 5, pp. 746-751, 1951.

[30] G. D. Christian, Text Book of "Analytical Chemistry", John Wiley \& Sons, Singapore, 2007.

[31] G. H. Jeffery, J. Bassett, J. Mendham, and R. C. Dennery, Vogel's Textbook of Quantitative Chemical Analysis, The Bath Press, Great Britain, UK, 5th edition, 1989.

[32] B. R. DasGupta and D. A. Boroff, "Quantitative spectrophotometric determination of hydrogen peroxide with paradimethylaminobenzaldehyde," Analytical Chemistry, vol. 40, no. 13, pp. 2060-2062, 1968. 


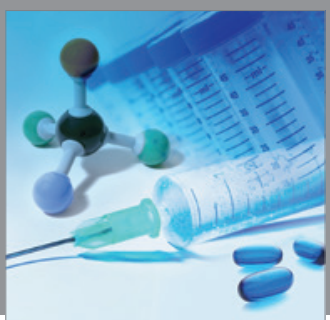

International Journal of

Medicinal Chemistry

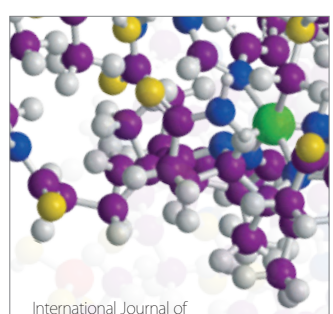

Carbohydrate Chemistry

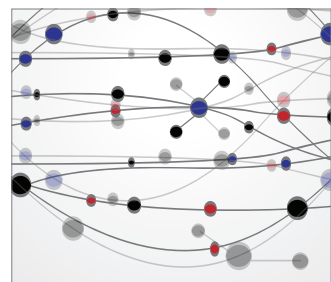

The Scientific World Journal
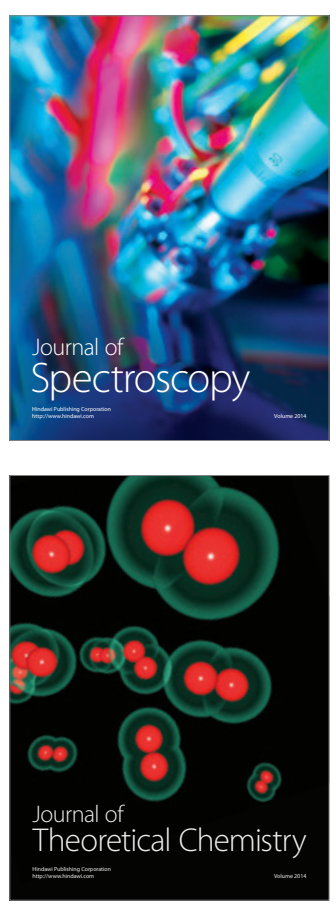
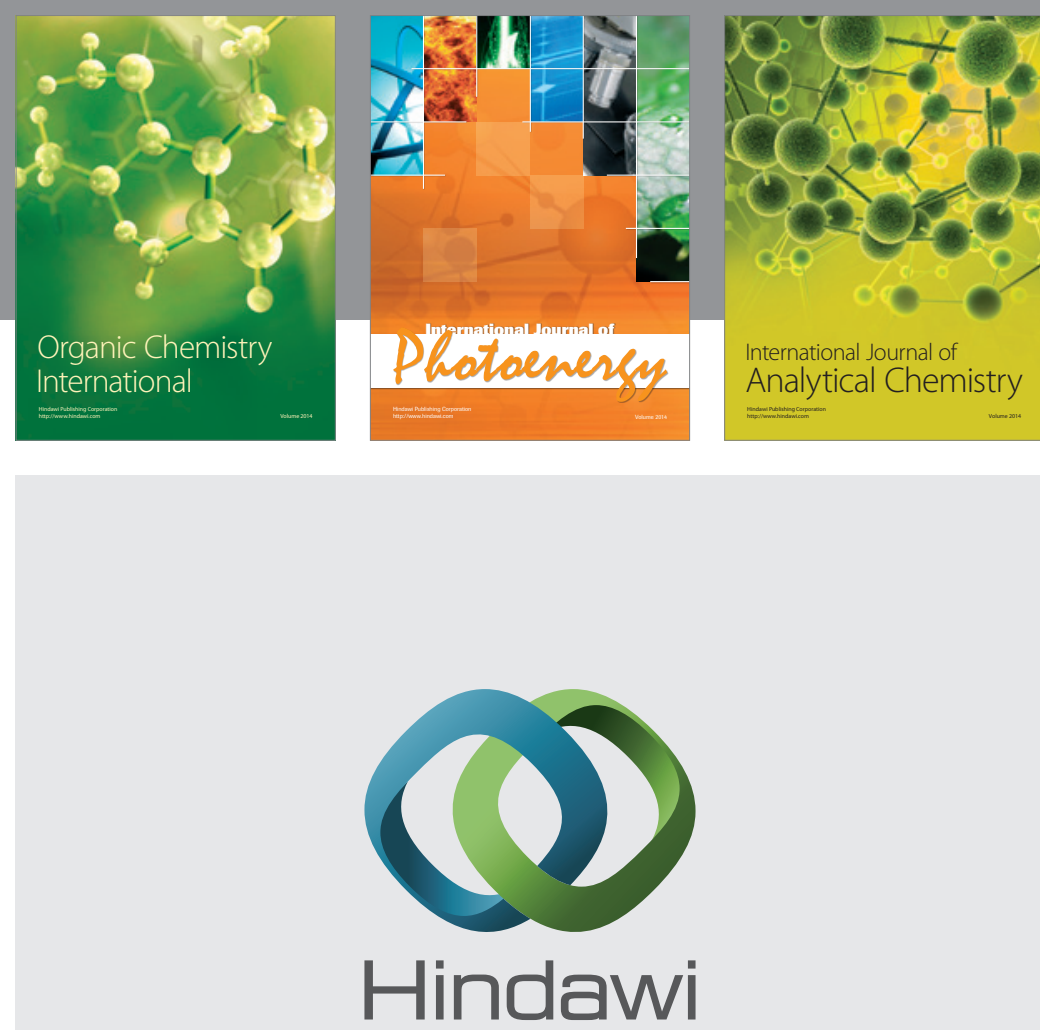

Submit your manuscripts at

http://www.hindawi.com
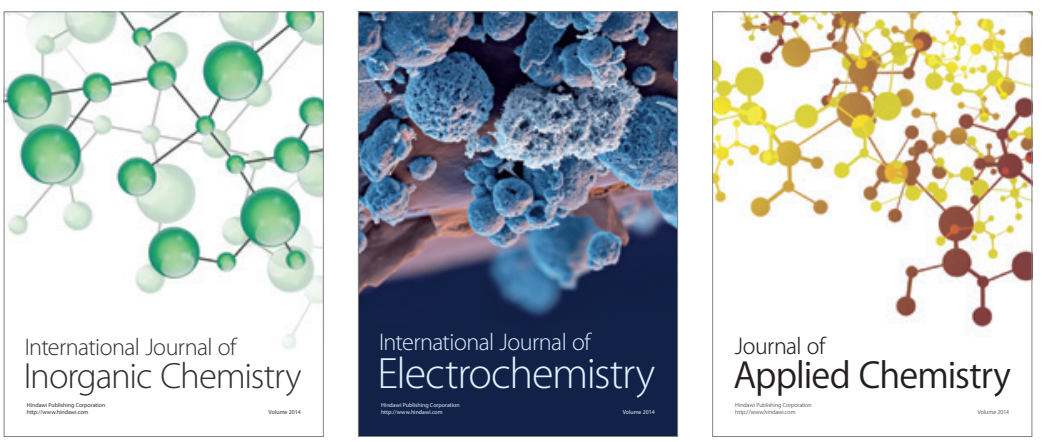

Journal of

Applied Chemistry
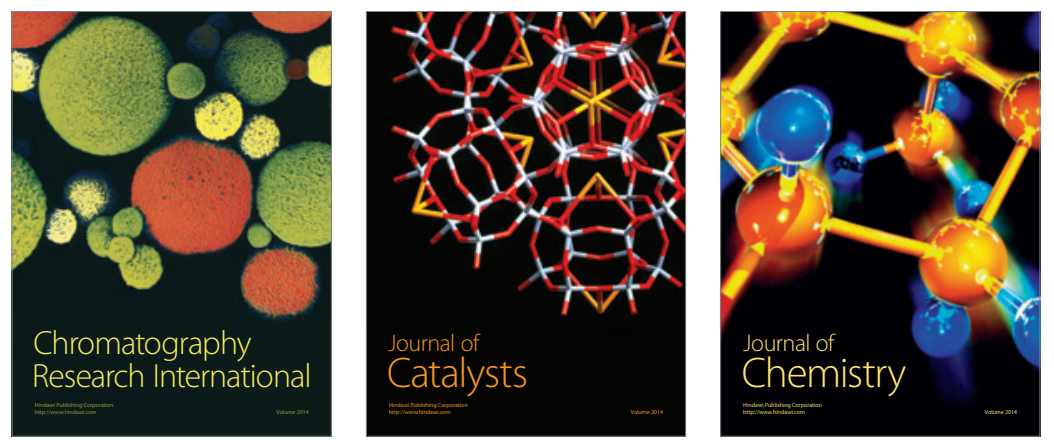
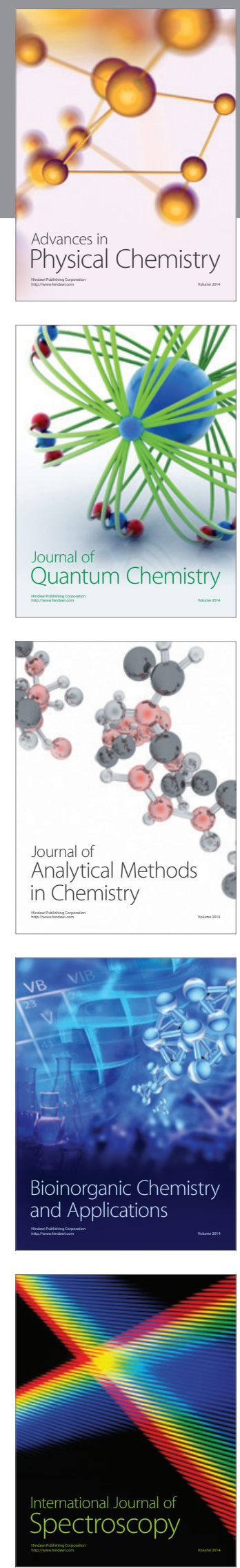